\title{
Searching the Damaged Outgoing Feeder in Networks with Insulated Neutral by Phase-to-ground Fault
}

\author{
Vitaliy Sivokobylenko, Volodymyr Dahl East Ukrainian National University, \\ Dmitriy Kuzmenko, Volodymyr Dahl East Ukrainian National University
}

\begin{abstract}
The method of searching the damaged feeder was improved by alternate disconnecting of feeder circuit-breakers, which allow to enlarge reliability of the systems of power supply by diminishing the number of multiple earth fault in electric network. Diminishing the number of multiple earth faults is attained by exception of switching overvoltage, because commutations of feeder circuit-breakers are carrying out when shunting circuit breaker is closed. The detection of damage in the feeder, when this method is used, is produced on the change of phase of current in the circuit of shunting circuit breaker after disconnecting of circuit-breaker of this feeder.
\end{abstract}

Keywords: electric network, isolated neutral, overvoltage, phase-to-ground fault, shunting of earth fault.

\section{INTRODUCTION}

Electric networks with the insulated neutral are widely adopted in the systems of power supply. The scientific studies [1] - [5] are devoted the methods of increasing of reliability of work of these electric networks, in which authors spare basic attention to perfection of devices of selective protection and signaling. However, in these papers, to the question of searching the damaged feeder by the earth faults not enough attention was spared. In networks with the insulated neutral by voltage 6-35 кB the most frequent types of damage are dead or arc earth-faults of phase. In most cases, when these damages begin, the immediate disconnecting of damaged feeder is not required, but assumed, during of some time (2-6 hours), a work of the network with the earth fault to detection the damaged feeder. In networks with the insulated or resonanceearthed neutral, when currents of the earth faults are not exceed 2-5 A the devices of selective signaling are working unreliably and so searching of damaged feeder is produced by alternate circuit breaker opening, which are connected to the busbars of substation. Such disconnecting are accompanied by overvoltage that often led to origin of the multiple earth faults and subsequent disconnections of few feeders. In this connection actual is improvement of methods of increasing of reliability of work of foregoing networks in conditions of searching of feeder with damage.

\section{RESEARCHING TASK}

The task of researching the switching conditions is posed in this paper with using the method of mathematical simulation and development of method of searching of feeder with damage by using which switching overvoltage and their consequences absent.

\section{MATERIALS AND RESULTS OF RESEARCHES}

The method, offered at this paper, is based on improvement already known methods of shunting of phase, whereon was damage of isolation, by shunting circuit-breaker (Qsh) [6] [11]. At the before described methods of using the automatic shunting of phase, in case of occurring the earth-fault, it was related with translation of the arc shorting in dead, and also by increasing of safety service of electrical equipment. Substantial difference of the offered method is control the phase of current in the circuit of Qsh during existence of the earth fault. The offered diagram of connecting devices which are needed for using of the developed method is showed on a fig. 1 .

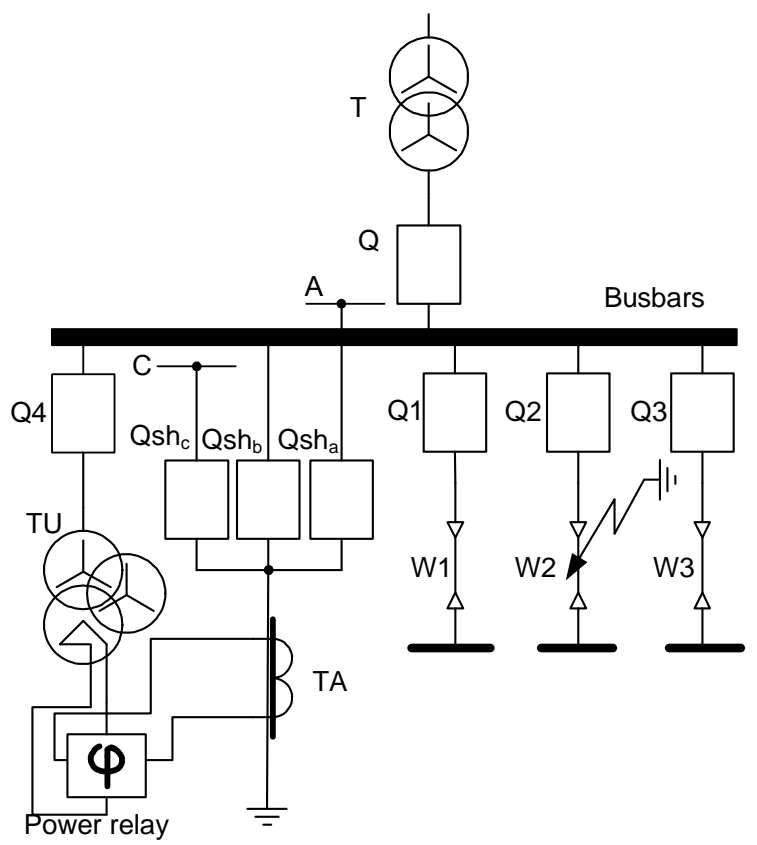

Fig. 1. Explaining the offered method chart.

On a fig. 1 the outgoing feeders W1-W3, which by the help of circuit-breakers Q1- Q3 are connected to the system of busbar section, the circuit-breaker Q4 connects to the system the voltage instrument transformer, on secondary winding of which neutral point displacement voltage is measured. Three shunting single-phase circuit-breakers of every phase Qsh(a-bc) are connected to this system of busbar. All three outputted phases of these circuit-breakers are united between themselves and they are earthed. The current instrument transformer is 
installed in the circuit of the indicated grounding, to the second winding of which the directional-power relay is connected. In the chart of control of shunting single-phase circuit-breakers protections are foresaw:

- on connecting of Qsh by the three-phase or double-phase short-circuit;

- on connecting of Qsh by single unrepetitive insulation failures;

- from an origin the double earth-fault by the connected circuit-breaker Qsh;

- from connecting of circuit-breaker Qsh of undamaged phase;

- from the simultaneous connecting of circuit-breakers of two different phases together.

At, indicated on a fig. 1, connecting of additional devices alternate disconnecting of feeder circuit-breakers, which is necessary for searching a damage, it is suggested to implement at the closed Qsh, and presence the earth fault in the outgoing feeder to determine on the change of corner to power after disconnecting of switch of this feeder.

In the damaged phase by using the offered method, two connections appear with earth, in place of shorting at the remote from substation outgoing feeder and in place of shunting a circuit-breaker, setting directly on the busbars of incoming substation. Disconnecting of the damaged and undamaged feeders, for account of additional artificial connection with earth, will not result in the discontinuity of capacity current of earth-fault and origin of overvoltage.

An effect of the offered method is confirmed by the results of mathematical and laboratory simulation.

For confirmation of effect of the offered method the mathematical simulation of diagram was built showed on a fig. 1, in which for researching of transients was used the system of differential equalizations.

The generalized differential-integral equalizations of legs, which contain R, L, C parameters and have next form, were fixed in basis of this model

$$
\begin{gathered}
e(t)=R \cdot i+L \frac{d i}{d t}+U_{c} \\
\frac{d U_{c}}{d t}=\frac{1}{C} \cdot i
\end{gathered}
$$

For provisioning of numeral stability the implicit methods of decision of equalizations (1) are used, in basis of which replacement of derivatives is made by the formulas of backward differentiation (2)

$$
\begin{aligned}
& i^{k+1} \cdot \frac{a_{0}}{h}+i^{k} \cdot \frac{a_{1}}{h}+i^{k-1} \cdot \frac{a_{2}}{h}=\frac{e(t)}{L}-\frac{R}{L} \cdot i^{k+1}-\frac{U_{C}^{k+1}}{L} \\
& U_{C}^{k+1} \cdot \frac{a_{0}}{h}+U_{C}^{k} \cdot \frac{a_{1}}{h}+U_{C}^{k-1} \cdot \frac{a_{2}}{h}=\frac{1}{C} \cdot i^{k+1}
\end{aligned}
$$

From equalizations (2) the variable states are determined

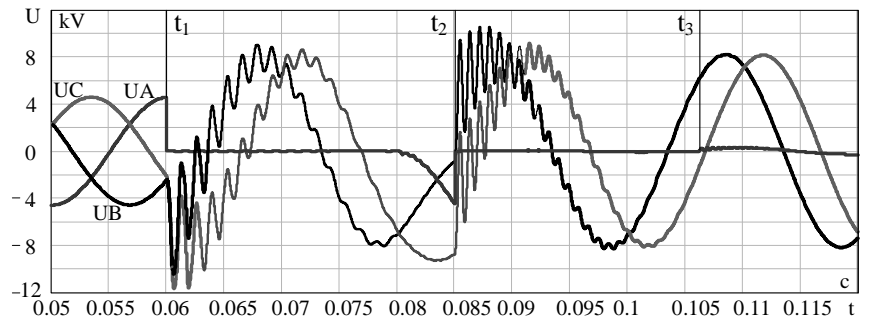

$$
\begin{aligned}
& {\left[\begin{array}{c}
i^{k+1} \\
U_{C}^{k+1}
\end{array}\right]=\left[\begin{array}{cc}
R+\frac{a_{0}}{h} \cdot L & 1 \\
1 & -C \cdot \frac{a_{0}}{h}
\end{array}\right]^{-1} \times} \\
& \times\left[\begin{array}{c}
e(t+h)-\frac{L}{h} \cdot\left(a_{1} \cdot i^{k}+a_{2} \cdot i^{k-1}\right) \\
\frac{C}{h} \cdot\left(a_{1} \cdot U_{C}^{k}+a_{2} \cdot U_{C}^{k-1}\right)
\end{array}\right]
\end{aligned}
$$

where $a_{0}, a_{1}, a_{2}$ are coefficients of the method; $h$ is a step of calculation; $\kappa+1$, к , к-1 are steps of calculation.

On the basis of higher described equalizations the mathematical model which is realized on computer as a Mathcad - program was created. By this program mathematical simulation of the modes of operations of the system of power supply of distribution network is executed by the earth-faults.

In researches, on the showed model, dependences of influences of shunting circuit-breakers were taken into account on steady-state and transitional processes in a network. By implementation of these researches influences were taken into account on:

- numerical value of zero phase-sequence voltage;

- distances of site of damage from the busbar of substation;

- commutations of circuit-breakers of damaged and undamaged feeders

- loading the damaged feeders.

In researching damage in feeder was simulated by the nonlinear, at function of time, resistance to the line W2 (fig. 1).

Character of transients in case of occurring of the arc shorting and subsequent connecting of Qsh is showed on fig.

An arcing earth, showed on a fig. 2, appears in the moment of $\mathrm{t} 1$, whereupon an arc goes out in first crossing of current through a zero.

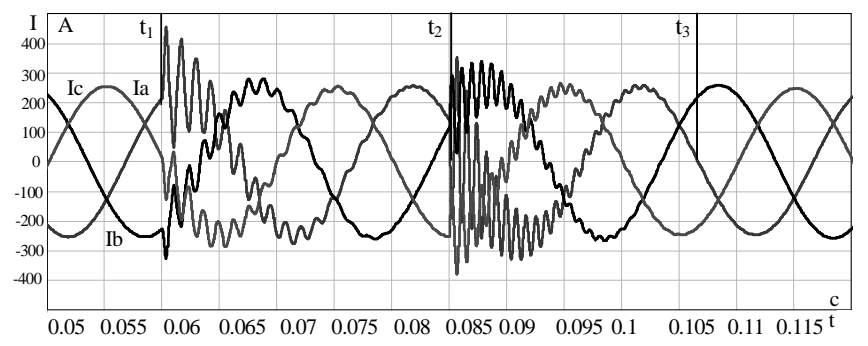

a)

b)

Fig. 2 Limitation of overvoltage after conversion of the arc shorting in dead. a) oscillograms currents of the damaged feeder;

b) oscillograms of linear voltage of transformer 
A overvoltage appeared by breakdown arrives at $12 \kappa \mathrm{B}$, that is more nominal in 2,5 time. A shunting circuit-breaker is connected in the moment of $\mathrm{t} 2$ and changes the arc shorting in dead; in this case voltage on unbroken phases is not exceeded $8 \mathrm{\kappa V}$. Disconnecting of circuit-breakers of unbroken feeders of Q1 takes place in the moment of $\mathrm{t} 3$, commutation overvoltage are absent there.

The oscillograms of currents and voltage of instrument movements of relay defence are showed on a fig. 3, at flowing processes described early. It is necessary to mark that during researches of transients the errors of measuring transformers were not taken into account in circuits of relay defence. For evidentnes this oscillograms were gotten at the power-offed switch Q3. In the time of connection of shunting circuitbreaker, the moment $\mathrm{t} 2$, blackout of arc take place in the site of damage of isolation and discharge of capacities of
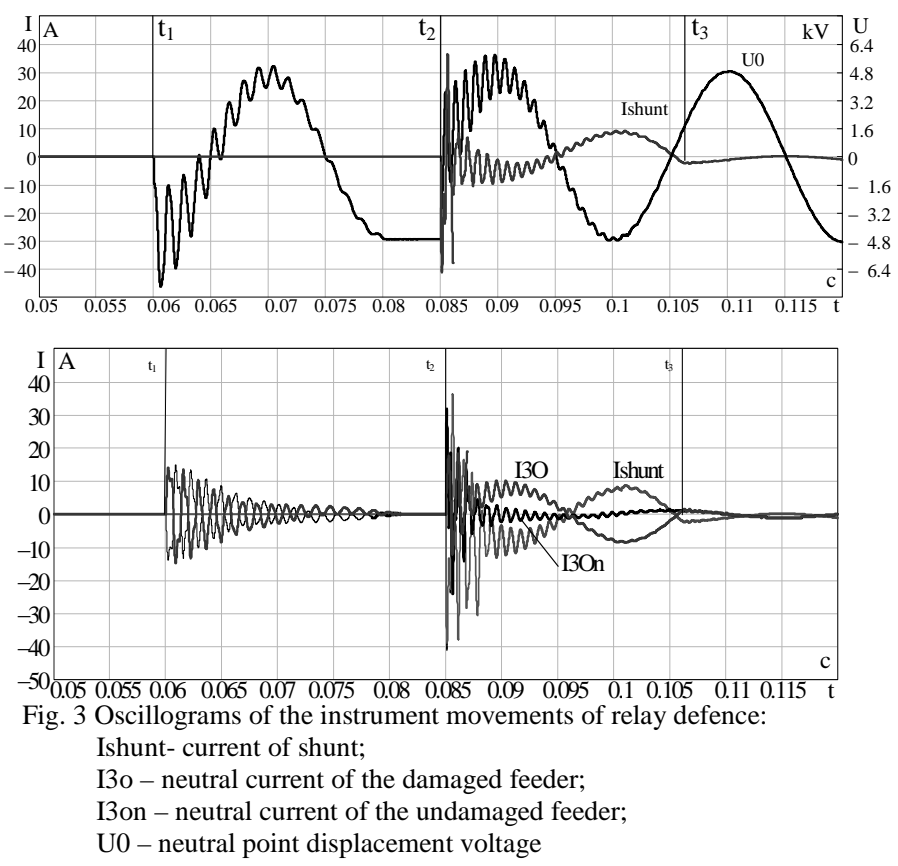

undamaged phases of the connected feeders take place through the chain of shunting circuit-breaker. Further forced disconnecting of undamaged feeder $\mathrm{W} 1$ in the moment $\mathrm{t} 3$ is flowing after blackout of arc current in place of damage of isolation, that promote the decline of levels of overvoltage at searching the feeder with shorting.

Along with the arc shorting during the researches dead (metall) were simulated also. At the simulate of these shorting with the subsequent switching of Qsh the increase of active component of currents was exposed in the circuit of this circuit-breaker and place of damage. This effect is caused by the partial taking of current of loading of the damaged phase from place of shunting to the place of shorting. The value of change an active component depends on distance to the site of damage and volume loading in the damaged feeder. It is possible to judge by control this component about type of damages and to control course of search of the damaged feeder by the by turn disconnecting of switches.
Showed on a fig.4 dependences of corner of current in the place of shunting were got by mathematical simulation.

Curve 1 (fig. 4) shows dependence of corner between a current in the circuit of Qsh and voltage of zero phasesequence from the value of transitional resistance in the place of damage. This dependence is correct to the moment of disconnecting of switch of the damaged feeder. The phase of current, as showed this curve, depends on resistance in the place of shorting, and it's values, by resistance 2-20 Om, considerably differ from the values of phase of current of curve 2. Curve 2 (fig. 4) shows that after disconnecting of the damaged feeder a current in the place of shunting have only a capacity character and corner near to $-90^{\circ}$.

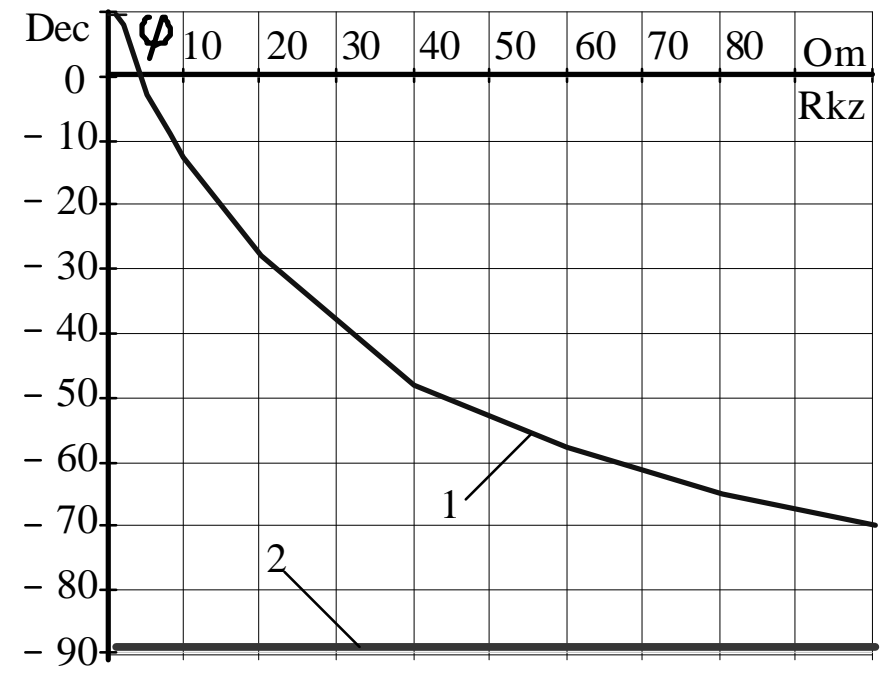

Fig. 4 Is dependence of readouts of phase meter on transient resistance in the place of earth-fault:

1 - at presence of the damaged feeder;

2 - after disconnecting of the damaged feeder.

Analogical dependences were gotten at researching of influence of remoteness of place of damage and loading of the damaged feeder on the phase of current in the circuit of Qsh.

Adequacy of mathematical simulation is confirmed by the good coincidence of results with laboratory researches.

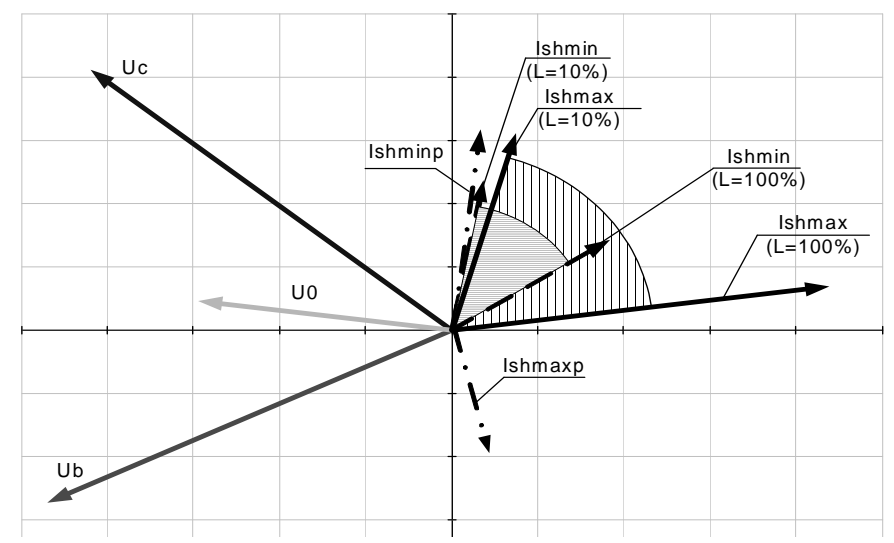

Fig. 5 Diapasons of current corner of shunting circuit-breakers varying with the load of feeder and distance of place of damage from the beginning of cable 
Two diapasons of changing of phase of current in the circuit of shunting circuit-breaker, fig. 5, are marked the cross-hatch sectors. Indicated dependences were got an experimental way. Both diapasons were got by a change to the degree of loading of the damaged feeder on condition that a power-factor of loading was within the limits of values $0,8-0,9$. Vectors of current of this leg were gotten by a mathematical simulation, on this figure inflicted by dash-dotted lines and corresponded to the scopes of the expected change of corner. Thus the corner of vector of Ishmin corresponds to the value of corner of current, calculated on condition of absence of loading in feeder, and coincides with the value of corner of this current, calculated on condition of complete loading of feeder but a zero distance from the busbars of substation to the site of damage.

For the practical using of the developmented method it is recommended to set additionally on each of phases circuitbreakers, connected to the busbars with monophases controlling, in the circuit of connection this circuit-breakers with earth, set the current transformer, the secondery winding of which is connected to the amperemeter and phase meter, the relay of directed power can be applied for automation it's process.

It is necessary to connect to the voltage transformer of the system of busbar of substation the device of choice of the damaged phase [12] by which a command is given on switching proper the damaged phase of circuit-breaker and to works satisfy of this damage signaling. In such mode, artificial of dead earth-fault, an electric network is working to arrival of men on duty. After arrival men on duty by reading of phase meter determines the type of damage (arc or dead) and determines the state of damage (in the case of the arc shorting) by the trial disconnecting of shunting circuit-breaker (in the case of origin of the intermittent fault, in time of arrival of men on duty, autoreduction of dielectric strength of isolation of arc interval is possible).

In cases autoreduction of isolation of arc interval is not possible men on duty make by turn disconnecting of circuitbreakers of feeders and expose the feeder with damage.

\section{CONCLUSIONS}

1. The method of searching the damaged feeder is offered by using which interconnects overvoltage is absent, that allows increasing reliability of electric networks with isolated neutral.

2. Suggesting method is based on shunting of the damaged phase by the help of circuit-breaker and control of phase of current in this circuit by the alternate disconnecting of circuitbreakers of the outgoing feeders.

3. By developed mathematical model of distributive electric network 6-10 kV dependences of influence of the state of shunting circuit-breaker were goten, distance from step-down substation of site of damage and load in the damaged feeder on the current of neutral in the place of shunting.

\section{REFERENCES}

[1] Шалин А.И., „Замыкания на землю в сетях 6-35 кВ. Случаи неправильных действий защит," Новости ЭлектроТехники, 2005, № 2(32), С. 58-61.

[2] Базилевич М.В., Сабадаш I.О., „Захист від замикань на землю в мережі $з$ ізольованою нейтралью,” Зб. наук. пр. ДонДТУ. Серия: Електротехника і енергетика, випуск 21, Донецьк: ДонДТУ, 2000, C. $93-96$.

[3] Шабад М.А., „Обзор режимов заземления нейтрали и защит от замиканий на землю в сетях 6 - 35 кВ России,” Энергетик, 1999, № 2, C. $11-13$.

[4] Sokansky K., Gavlas J., Valek P., "Possibilities of Identification of earth faults in $22 \mathrm{kV}$ Distribution Networks," Short-circuit currents in power systems, 9 th International Symposium, Cracow, October $11-13,2000$, C. $157-163$.

[5] Дергилев М.П., Обабков В.К., „Перенапряжения в сетях 6-10 кВ с двигательной нагрузкой при различных способах заземления нейтрали," Ограничение перенапряжений и режимы заземления нейтрали сетей 6-35 кВ: Тр. второй Всероссийской науч.-техн. конф. - Новосибирск, 15-17 окт. 2002, С. 106-112.

[6] Красянський В.М., Бондаренко Л.Г., Фещенко П.П., Саптоцький В.Г., „Автоматичне шунтування фази в электричних мережах $6-10$ кВ 3 ізольованою нейтраллю," засіб централізованого підвищення безпеки, Енергетика и єлектрификация, 1997, № 6, С. 39 - 41.

[7] Подьячев В.Н., Плессер М.А., Беляков Н.Н. и др., „Глубокое ограничение перенапряжений при замыканиях на землю в сети 6 кВ собственных нужд ТЭС, ” Энергетик, 1999, №2, С. 20 -21.

[8] Сивокобыленко В.Ф., „Повышение надежности работы сетей $6-10$ кВ при замыкании фазы на землю,” В.Ф. Сивокобыленко, Д.И. Кузьменко, Праці Луганського відділення Міжнародної Академії інформатизації, Луганськ, 2007, Випуск 2 (15) 2007, Ч.1, С. 50-53.

[9] Барановская Мила Леонидовна., „Повышение эффективности работы распределительных сетей 6-10 кВ с изолированной нейтралью при замыкании фазы на землю," Дис. канд. техн. наук: 05.14.02, Криворожский технический ун-т, Кривой Рог, 2004, 245л., рис., Библиогр, л. 155-166.

[10] Сабарно Людмила Ростиславівна, „Методи та пристрої селективного контролю стану ізоляції розподільної мережі 3 ізольованою нейтраллю," дис. канд. техн. наук: 05.14.02, НАН України; Інститут електродинаміки, К., 2005.

[11] Кузьменко Д.И., „Влияние несимметрии параметров распределительной сети 6-10 кВ с резонансно заземленной нейтралью на характер переходного процесса при замыкании фазы на землю," Д.И. Кузьменко, Вісник СНУ ім. В. Даля., Луганськ: СНУ ім. В. Даля., Випуск 4 (110), Ч.1., С. 188-192.

[12] Нанаяккара Ахангама Виданаге Махинда Сильва, „Совершенствование режимов работы сетей 6 кВ собственных нужд электростанций при замыкании фазы на землю," Дис. канд. техн. наук: 05.14.02, Донецкий национальный технический ун-т., Донецк, 2001, 182л., Библиогр.: л. 165-180.

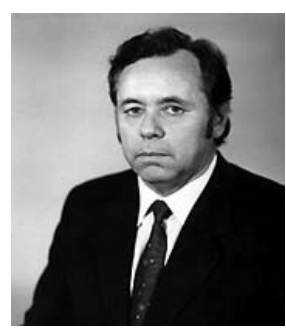

Vitaly Sivokobylenko, 1934 year of birth, Ukraine, finished off the Kharkov polytechnic institute, d.t.n., professor of chiar of the electrotechnical systems of power supply Volodymyr Dahl ENU. Basic direction scientific activity is a mathematical modelling of transients and increase of reliability of work of the systems of power supply of auxiliaries of powerstations and industrial enterprises.

Dmitriy Kuzmenko, 1975 year of birth, Ukraine, finished off the Volodymyr Dahl East Ukrainian National University, assistant of chiar of the electrotechnical systems of power supply Volodymyr Dahl East Ukrainian National University.

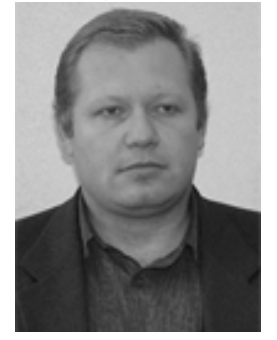

